\title{
Faglige inntrykk fra IASP-kongressen i Oslo
}

Ved Gudrun Austad

\section{Det var en glede å få være til stede på den 27. IASP-kongressen i Oslo 24.-28. september 2013. Hovedstaden viste seg fra sin beste side så lenge konferansen varte, og både Munchmuséet, operabygget og rådhuset ble tatt i bruk.}

Det var et omfattende og svært variert program vi fikk presentert. Antallet deltakere fra store deler av verden gjorde sitt til at det ble mange spennende samtaler rundt lunsj- og middagsbord.

For min del var konferansedagene preget av ambivalens. Valgets kval ble ekstra utfordrende med 2x12 paralleller å velge mellom hver dag. Heldigvis sitter jeg nå igjen med den 500 sider lange Book of abstracts, eller "telefonkatalogen", som den ble kalt på konferansen, og kan orientere meg om alle temaene jeg valgte bort, samt de 174 posterne. Her er noen av høydepunktene jeg fikk med meg.

Siri Hustvedt, norskamerikansk skjønnlitterær forfatter, holdt åpningsforedraget "Suicide and the Drama of Self Consciousness", og satte tonen for resten av konferansen. Selvmord som samfunnsproblem kan ikke forebygges av én faggruppe eller én teoretisk retning alene. Selvmordsforebygging er i høyeste grad en tverrog flerfaglig oppgave. Det er også hovedinntrykket etter konferansen. Det skjer mye, både på forskningsog intervensjonsfronten i verden når det gjelder selvmordsforebygging. Mye er nytt og mye er kjent fra før.

Det var interessant å høre hvordan økonomiske nedgangstider og finanskrisen har innvirkning på selvmordsatferd. Noen land der krisen har rammet har også sett økning i selvmordsrater. Andre land, som Island og Japan, har ikke hatt en slik økning. David Stuckler viste hvordan et lands økonomi og helsepolitikk blir et spørsmål om liv og død.

Eldre fikk en tydelig plass på konferansen, både i plenum og i parallellsesjoner, der sosiale faktorer, risikofaktorer og forebyggingsprogrammer ble lagt frem. Arbeidet til Elene Fleischer og Gert Jessen i Danmark er vel verdt å merke seg og kan følges på www.ensomhed.info.

Internett og sosiale medier er en ny arena for spredning av selvmordstanker, forebygging av selvmord og behandling. Mye forskning gjøres på bruk av sosiale medier og selvmordsatferd, samt hvordan forebygge selvmord ved hjelp av sosiale medier. Hjelpetelefoner bruker også Internett og chattetjenester i sin kontakt med unge mennesker spesielt. E-læringsprogrammer for gatekeepere og web-basert behandling ble presentert i flere parallellsesjoner. Et eksempel er EUREGENAS (European Regions Enforcing Actions Against Suicide), et 3-årig prosjekt finansiert av EU.

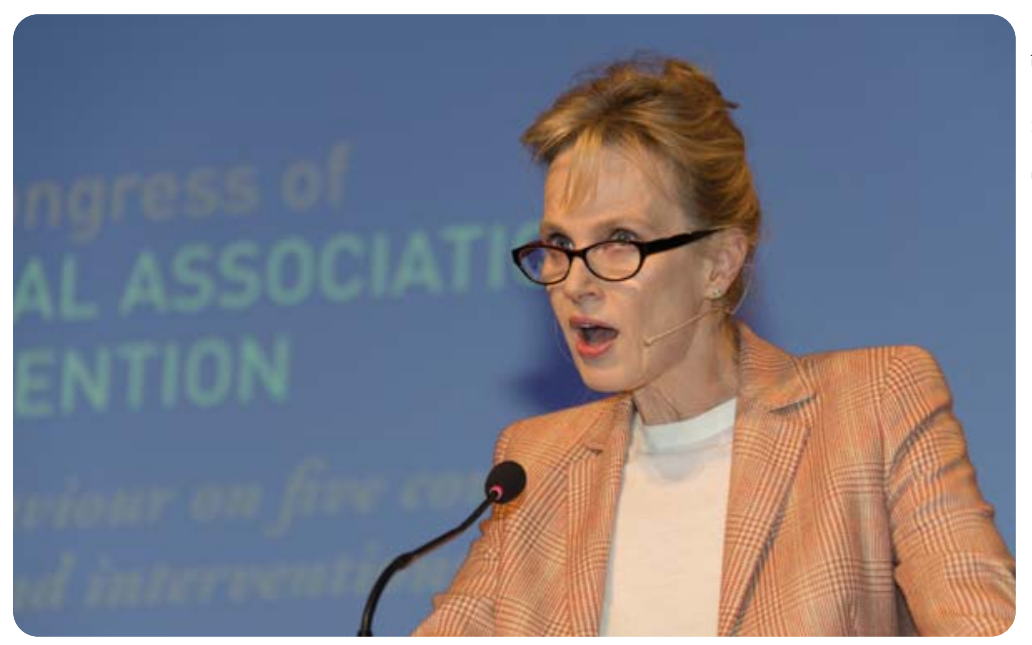

Siri Hustvedt satte med sitt åpningsforedrag tonen for konferansen

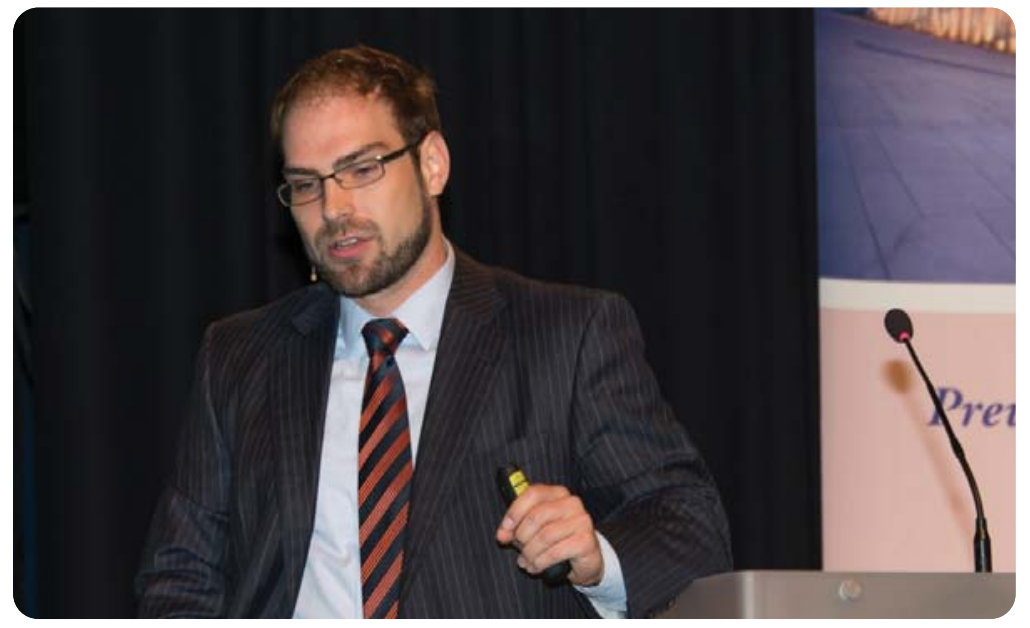

David Stuckler presenterte sammenhenger mellom økonomi og selvmordsatferd

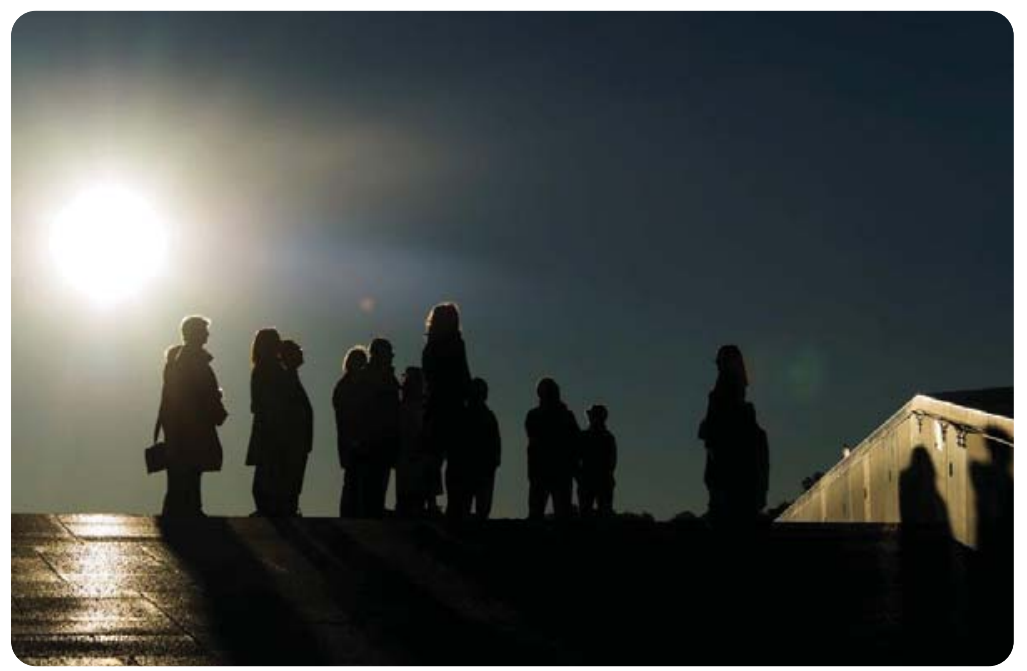

Mindfulness på taket av operaen 

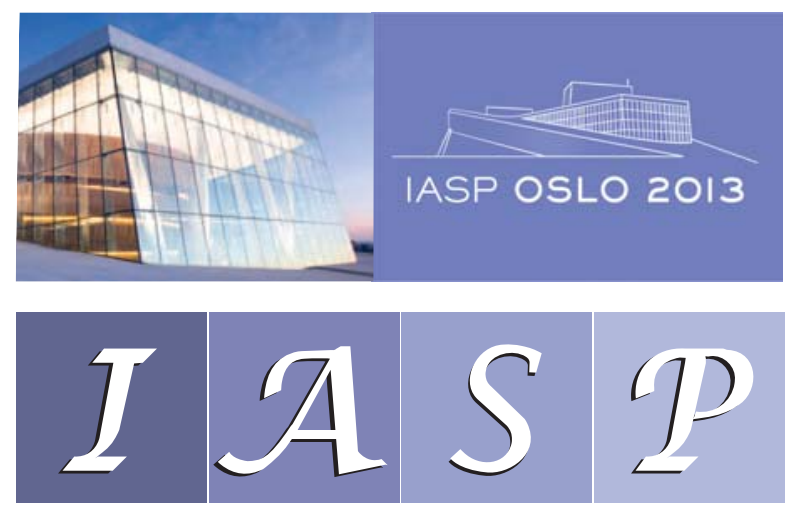

Målet er å bidra til forebygging av selvmord i Europa gjennom utvikling og implementering av selvmordsforebyggingsstrategier regionalt, som kan brukes som eksempler på god praksis. De skal utvikle en integrert modell for e-mental helse. Les mer på www.euregenas.eu. Når det gjelder bruk av Internett og sosiale medier er suicidologien i startgropa, og dette temaet er nok kommet for å bli også på fremtidige konferanser.

Selvmordsproblematikkens verdensbilde ser annerledes ut sett fra Europa enn det gjør fra Asia. Mark Philips fra Kina satte selvmordsforebygging i perspektiv da han påpekte at $84 \%$ av verdens selvmord skjer i lavog mellominntektsland, mens det meste av forskningen skjer i høyinntektslandene, der $16 \%$ av verdens selvmord forekommer. Sett i dette perspektivet er den vanligste selvmordsmetoden på verdensbasis inntak av plantevernmidler. Restriksjoner i tilgangen til plantevernmidler viser seg å være et svært effektivt selvmordsforebyggende tiltak der slike midler er i bruk.

Tonen Siri Hustvedt satte, holdt seg gjennom hele konferansen. Temaene var mange og perspektivene likeså. Nevrobilder, behandlingsstudier, selvmordsclustere og smitte, selvskading, selvmordsrisikovurdering, psykiske lidelser og selvmord, postvensjon, mobbing, alkohol og selvmordsatferd, negative livshendelser, gatekeeperopplæring, etniske og kulturelle faktorer, forebygging på arbeidsplassen, selvmord i konfliktområder, ambivalens, resiliens, traumer, hjelpetelefoner, jernbaneselvmord, diabetes og selvmord var bare noen av temaene. En konferanse som denne bringer oss kanskje et lite skritt nærmere effektiv forebygging og behandling av det globale problemet selvmord er.

Og mens vi satt inne og hørte på foredrag om Internett og sosiale mediers rolle i økning, forebygging og behandling av selvmordsatferd, ble det samtidig twitret til resten av verden om det som ble hørt og sett på \#IASP2013.

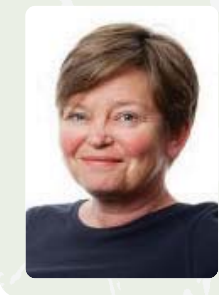

Gudrun Austad er psykiatrisk sykepleier med master i Psykososialt arbeid - selvmord, rus, vold og traumer. Hun er ansatt ved RVTS Vest, sitter i landsstyret i Kirkens SOS og er veileder i VIVAT selvmordsforebygging.

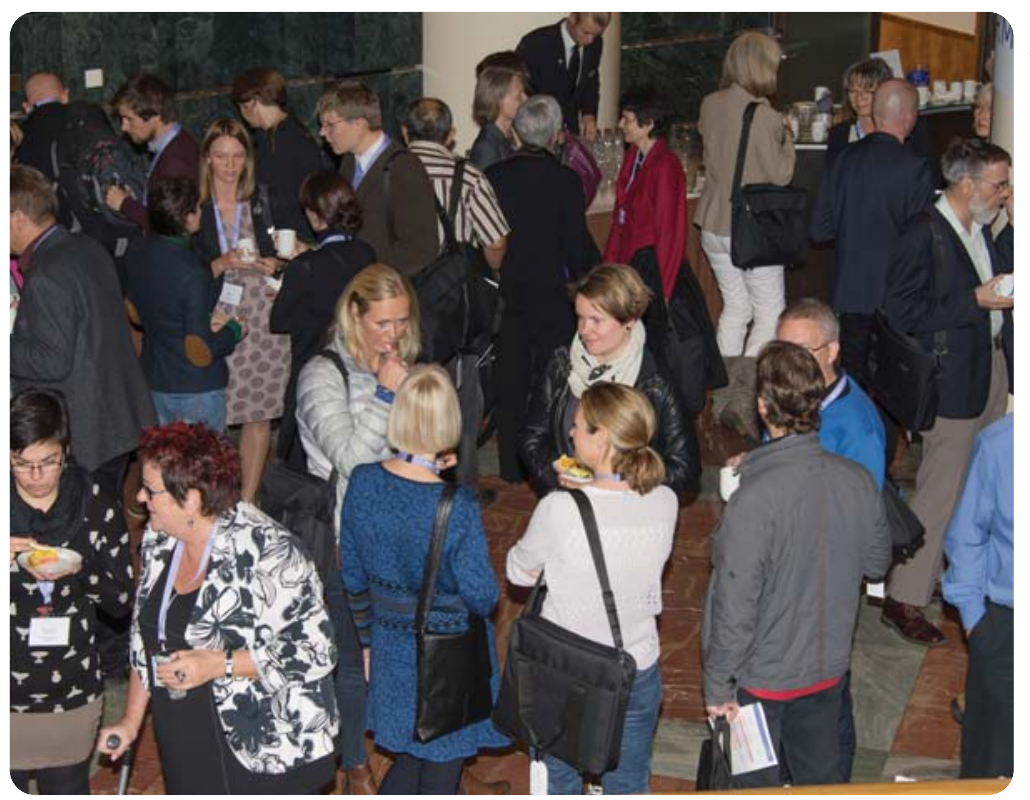

Praten og diskusjonene gikk livlig i pausene

Lifeline@LifelineAust

25.09 .13

Our Research Foundation for \#SuicidePrevention Director Alan is at \#IASP2013. With 40 Aussies there, we punch above our weight in this field

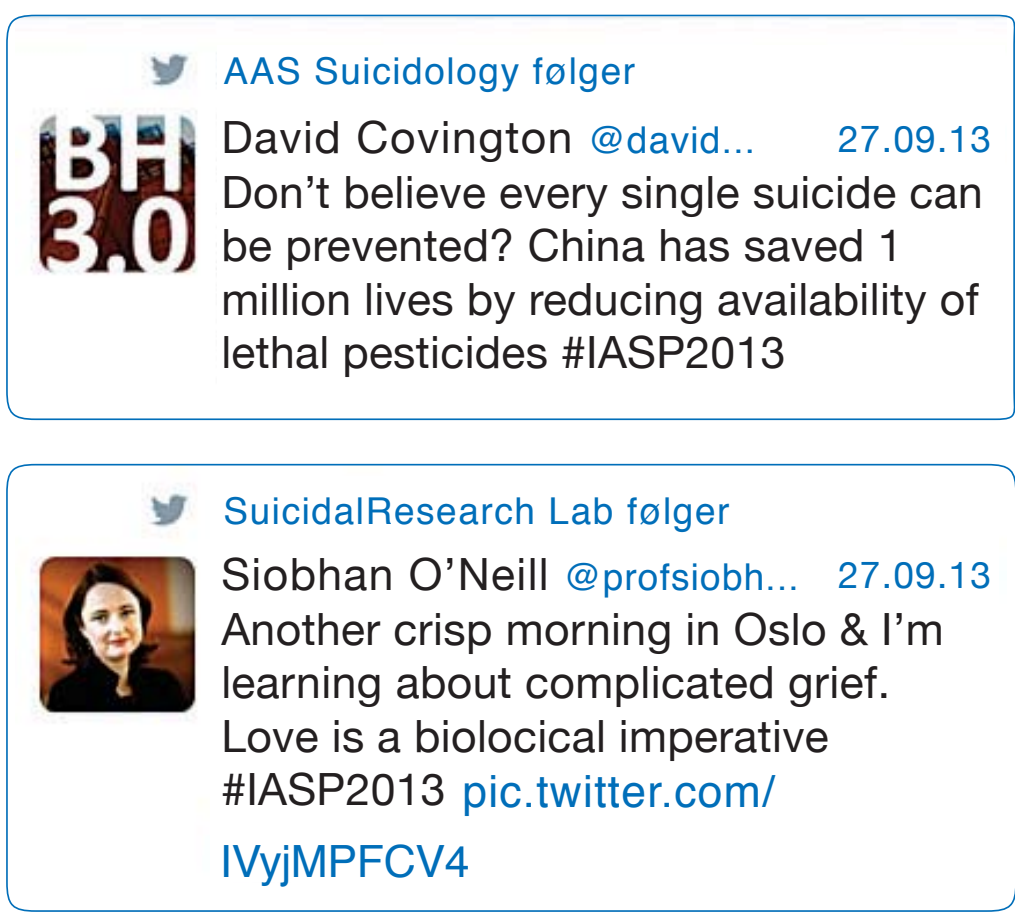

Twitter-meldinger fra konferansen 